\title{
Does The Price Puzzle Exist in Colombia? Empirical Evidence and Policy Implications *
}

Blen Solomon

Isabel Ruiz ${ }^{1}$

\section{Introduction}

The positive response of prices to an increase in interest rates or contractionary monetary policy has been documented by several empirical studies. ${ }^{2}$ According to monetarist as well as IS-LM models, an increase in interest rates or contractionary monetary policy reduces aggregate demand leading to a decrease in the price level. As a result, this positive response of prices to positive interest rate shocks is perplexing and is referred to as the price puzzle. Sims (1992) set out to examine existing theory and evidence on the effects of monetary policy by using VAR methodology. He observed a positive response of the price level to contractionary monetary policy shocks, which was positive for many quarters. Sims speculated that the information set available to policy makers might include variables that are useful in forecasting future inflation that the econometrician has not yet considered. He believed the world commodity price to be one of these information variables and therefore proposed the inclusion of the commodity price to alleviate this problem. Consequently, he found that, when the VAR is extended to include a commodity price index, the puzzle almost disappears for the US.

\footnotetext{
We would like to thank Mark Wheeler and an anonymous referee for helpful comments and suggestions. All remaining errors are ours. Fecha de recepción: Enero 27 de 2006, fecha de aceptación: Febrero 22 de 2006

I Corresponding author: Blen Solomon, Department of Economics, Western Michigan University, Kalamazoo, MI 49008. Phone: (269) 387 - 1091. Email: blen.solomon@wmich.edu

1 Department of Economics Western Michigan University And Universidad EAFIT

2 For example, Sims, C. A. (1992) "Interpreting the Macroeconomic Time Series Facts", European Economic Review 36. PP. 975-1000.
} 
Following Sims (1992), some studies that make use of the VAR methodology to investigate the effect of monetary policy shocks in the US include the commodity price in order to account for the price puzzle (see Kim (2001)). However, some studies show that the price puzzle arises not due to the exclusion of the commodity price but the erroneous policy instrument used by the econometrician. Studies for the U.S. such as Eichenbaum (1991) has proposed alternative methods of identifying monetary policy shocks. He uses non-borrowed reserves instead of the Federal funds rate as a policy instrument. Strongin (1995) however, pointed out that a positive innovation in non-borrowed reserves was associated with declining interest rates, so this positive shock should result in increasing prices. However, the positive innovation in non-borrowed reserves resulted in declining prices contrary to a priori expectations. He therefore proposed a representation of the Federal Reserve's operating procedures that included additively both the level of total reserves and the mix of borrowed and non-borrowed reserves.

Bernanke and Mihov (1998) on the other hand, suggested a linear combination of innovations in total reserves, non-borrowed reserves and the federal funds rate as monetary policy shocks. The combination of these policy instruments enabled them to take into account the Federal Reserve's response to shocks in the demand for borrowed reserves. Their model includes as special cases the identification schemes based on the federal funds rate innovations as well as Strongin's approach. However, the absence of a price puzzle in their study is attributed to the inclusion of the commodity price index.

A number of studies have documented that the positive correlation between interest rate increases and subsequent increases in prices does not appear to be uniform over the postwar period. Balke and Emery (1994) found that the price puzzle to be much stronger during the pre-1980 period than the post-1980 period. They put the commodity price into their VAR framework and find that while including commodity prices fully eliminates the price puzzle in the post-1980 period, the puzzle is still present in the pre-1980 period. They conjecture that post 1980 the Federal Reserve has put more emphasis on achieving price stability and, hence, has responded more strongly to inflationary shocks, or there basically have been fewer large inflationary shocks to the economy.

On the other hand, Giordani (2001) stated that the best method of solving the price puzzle implies a close connection between theory and empirics rather 
than the introduction of a commodity price. He stated that "a wide class of models produce a price puzzle when subjected to an innocent misspecification common to applied research: only output is used in applications while theory also speaks of the output gap". ${ }^{3}$ If the central bank has the output gap in its inflation equation and there are lags in the transmission of monetary policy, then policy affects output first and then inflation. If this is the case, the omission of output gap causes interest rates to react positively to output gap increases, and acts as a proxy to the omitted variable (the output gap). He used a 3 variable VAR framework for U.S. quarterly data from 1970:1 to 2000:2 to test this prediction. His variables are short-term interest rate, prices, and output gap. His results pointed out that for the U.S.; the omission of a measure of output gap produces a price puzzle.

Some studies have developed a VAR model including 'information variables' to observe if the inclusion of these variables lessens the extent of the price puzzle. Brissimis and Magginas (2001) suggested augmenting a standard VAR with a small number of variables that have forward-looking informational content. The most important forward-looking variable Brissimis and Magginas (2001) included was the federal funds rate reflecting future expectations of monetary policy. They state that if the Fed is forward-looking, the policy response cannot be properly identified unless expectations are taken into account. They use U.S. monthly data from 1989-2001 and use their augmented VAR to show that, this augmented VAR was capable of producing theory-consistent responses to monetary policy shocks.

In the same fashion, Hansen (2004) used the Bernake and Mihov (1998) model of monetary policy and surveyed a wide range of "information variables" to investigate if some of these variables help alleviate the price puzzle. Hanson (2004) used monthly U.S. data to investigate if this model of monetary policy helps alleviate the price puzzle. Contrary to Brissimis and Magginas (2001) findings, he discovered that even though some of the information variables help lessen the extent of the price puzzle, several specifications indicate that the price puzzle still exists.

Yet another explanation of the price puzzle comes from Kapinos (2004). He conjectures that an alternative explanation for this puzzle is the presence of the cost

3 See, p. 3, Giordani, P. (2001) 'An Alternative Explanation of the Price Puzzle', Sveriges Risk Bank Working Paper Series, No. 12. 
channel of transmission of monetary policy, whereby interest rates enter a firm's cost function. In this setup, a contractionary monetary policy shock raises interest rates and hence the firm's marginal cost. In the very short term, this increase in cost translates into an increase in prices, which later decline due to the decrease in aggregate demand. Hence models that incorporate the cost channel may be able to explain the 'price puzzle'. For the purpose of his study, he presented a New Keynesian model capable of generating the price puzzle and examined the role of the cost channel in the empirical environment. He employed a VAR that used a dataset starting from 1983:1-2003:2 taken at monthly and quarterly frequencies. He concluded his study by stating that the price puzzle is evident in the monthly but not in the quarterly data. The existence of the price puzzle in the monthly data can indicate that, firms may raise prices in response to a monetary contraction, because of the assumption that nominal interest rates enter their cost function.

All the studies mentioned above, used U.S. data to investigate the price puzzle. Therefore it is imperative to look at other studies that have used non-U.S. countries. One study that estimated the impulse responses functions for non-U.S. countries is Jarosinski's (2002). He estimated impulse responses for 4 of the big Euro-zone countries namely, France, Germany, Italy and Spain. He used a Structural VAR framework for his analysis and he found that the price puzzle did not exist in these economies.

As illustrated above, the price puzzle has been the focus of many studies, however, most of these studies have focused on developed economies and especially on the U.S. Owing to this tendency; we do not know if the VAR framework produces the price puzzle in developing economies. This is an important topic of research as it facilitates the understanding on the different channels of monetary policy. It also helps our understanding regarding monetary policy effectiveness and in the context of the Colombian economy, this is a main issue as the basic long-term target of Colombia's monetary policy is price stability.

As a result, this study investigates the existence of the price puzzle for the period 1980:5-2003:12 in Colombia by using Vector Error Correction Model (VECM). However our sample period is not characterized with a uniform monetary policy regime. Pre-1991 the Colombian central bank's operating procedures were not clearly oriented to stabilize price. The central bank of Colombia started inflation targeting in 1991. As a result, in the 1990's more emphasis has been put on 
achieving price stability and, hence, the central bank has responded more strongly to inflationary shocks. Therefore, post-1991 the relationship between interest rates and our variables of interest (prices and output) might have undergone some change. As a result, following Balke and Emery (1994) we divide our sample period into two parts and check for a structural break.

If confronted with the price puzzle, the 'information variable' we use for Colombia is the world food price index (instead of the world commodity index). This is due to the fact that Colombia is a big exporter of food products such as bananas, sugar and coffee. Therefore, movements in the world food price index might be one of the 'information variables' used by the central bank to forecast inflation in this economy rather than the commodity price index.

This study contributes to the literature due to the following reasons. First, it uses a Vector Error Correction model (VECM) to analyze the existence of the price puzzle. Second, it uses data from Colombia. Finally, it investigates the existence of the price puzzle before and after inflation targeting was launched.

\section{Data and Methodology}

This study fits data from Colombia to a VECM model to investigate if positive shocks to the interest rate result in price increase. The VECM approach allows tracing out the dynamic response of the economy to policy shocks and it also provides a means of observing the effects of policy changes under minimal identifying assumptions. ${ }^{4}$ The data sources for our variables are the International Financial Statistics (IFS), and the Colombian Central Bank 'Banco de la Republica de Colombia'. Monthly data from 1980:5- 2003:12 for money (M) and exchange rate (XR) was available from the IFS. On the other hand, data for industrial production $(\mathrm{Y})$, consumer price index $(\mathrm{P})$, and interest rates $(\mathrm{R})$ was available from the central bank of Colombia 'Banco de la Republica, de Colombia'.

An important concern that a researcher using the VAR methodology must deal with is how to identify contemporaneous relationships in the model. Various methods have been used for identifying VAR models. One method is the Choleski decomposition, which achieves identification by imposing contemporaneous restrictions on some of the parameters in the original system. In this paper, identification is achieved by Choleski decomposition of the reduced-form residuals.

4 All our estimations are performed in RATS. 
The Cholesky decomposition assumes that the contemporaneous system is recursive. This allows identification.

Christiano et al. (1998) justify their cholesky ordering by assuming that monetary policy influences other variables such as output and prices with a lag. Therefore, while Sims (1992) used the ordering interest rate $(R)$, money $(M)$, inflation rate $(\mathrm{P})$, and industrial production $(\mathrm{Y})$ placing the policy instrument $(\mathrm{R})$ at the beginning, Christiano et al (1998) put it at the end.

Following Christiano et al. (2001), and Kim (2001), the ordering of our fourvariable VECM is industrial production $(\mathrm{Y})$, monetary aggregate $(\mathrm{M})$, inflation rate $(\mathrm{P})$, and short-term interest rates $(\mathrm{R})$. Short-term interest rates are affected contemporaneously by money, prices and industrial production. An assumption we are making is that monetary authorities observe output, prices, and money before setting monetary policy. Assuming that the main monetary policy instrument is short-term interest rate, this ordering is theoretically consistent and intuitive.

An advantage of using VAR is that it allows estimating the impact of unexpected changes. We would expect that unexpected changes in one variable are the ones that will have significant impact on other variables. "Any monetary policy variable can be decomposed into a systematic and an unsystematic component. The systematic component of the variable can be estimated in a VAR. This VAR equation of the policy variable can be thought of as reflecting a central bank reaction function and any other endogenous non-policy influences on the variable.

In this paper, we initially fit a four-variable VECM with the following ordering: money $(\mathrm{M})$ and exchange rate (XR) was available from the IFS. On the other hand, data for industrial production $(\mathrm{Y})$, consumer price index $(\mathrm{P})$, and interest rates $(\mathrm{R})$. The four-variable VECM is estimated to observe the response of prices to positive interest rate shocks. If we see evidence that the price puzzle exists, we will estimate a separate six-variable VECM for in order to decipher if the addition of the world food price index (FP) alleviates this problem to some extent ${ }^{5}$. Due to the inclusion of the world food price index in the model, which is an international variable, the addition of the $\mathrm{XR}$ is warranted. The ordering of the six-variable VECM will be XR, FP, Y, M, P, and R.

5 See Sims 1992. 
However, before estimation our data go through a series of tests to check for unit root, cointegration and specification of the VAR lag length. In addition, we test for a structural break in our sample period of 1980:5 -2003:12. This is due to the fact that Colombia in 1991 adopted a new Constitution that made the central bank independent from the central government. In 1991, for the first time, the Colombian monetary authorities announced a quantitative inflation target. After 1991, the stance of monetary policy in Colombia has been defined in the context of a global objective, which has been to maintain moderate inflation.

Before, 1991 there was no clear distinction between the tasks of the central bank and those of the government with respect to macroeconomic management, nor was there any autonomy in the design and execution of monetary policy. Due to these factors, in 1991 the relationships between our variables might have undergone a change. As a result, we check for a structural break in our sample period by using the Chow break point test. ${ }^{6}$

\section{Empirical Results}

The results from the Augmented Dickey Fuller Test for unit root (table 1 in appendix) suggest that all the variables under consideration (R, M, P, and Y) are I (1) processes. Having verified that the variables are integrated of the same order, we test for a long-run relationship or cointegration between the variables. Engle and Granger (1987) illustrated that a VAR estimated with differenced data will be misspecified if the variables are cointegrated. Therefore, it is important to test for cointegration when our variables are integrated of the same order.

When the variables have unit roots and are cointegrated, a VAR model is no longer optimal. Instead, it is appropriated to estimate a vector of error correction model (VEC). A VEC model is a restricted VAR that has cointegration restrictions built into the specification, so that it is designed for use with nonstationary series that are cointegrated.

To test for the presence of cointegration between the variables, we use the Johansen (1991) Cointegration Test approach, employing the trace statistic. As is observable from table 2 (in appendix), the trace statistic rejects the null hypothesis

6 The breakpoint Chow test fits the equation separately for each sub sample and investigates whether there are significant differences in the estimated equations. A significant difference indicates a structural change in the relationship. 
that there is no cointegration. Therefore, we proceed to estimating with Vector Error Correction model (VECM) rather than the unrestricted VAR. In addition, a test for a specification of lag length was conducted and a lag length of 4 was selected by minimizing the Schwartz Information Criterion (SIC).

Moreover, before we proceed with the estimation we test for a structural break. The Chow test (table 3 in appendix) indicates that there was a structural break in 1991. Therefore we divide our sample period into two periods. The first period is pre-1991, before inflation targeting while our second period is during inflation targeting.

We now proceed with our VECM estimation, which allows for the evaluation of the impulse response functions. Our main focus is on the impulse response of prices to positive interest rate shocks. The impulse response function of prices to interest rate shocks for the pre-1991 period is shown in figure 3 (in the appendix). Impulse response functions are constructed with forecast horizons of 48 periods, and 1,000 Monte Carlo simulations are used to derive the two standard deviation confidence bands.

Figure 3 indicates that a shock to short-term interest rates does not produce a significant response in prices during the whole 4-year time span. Explanations of the unresponsiveness of prices to interest rate shocks might be due to the fact that the Colombian central bank's operating procedures were not clearly oriented to stabilize prices. This objective became strictly clear only for the post 1991 period. Therefore, during the pre-1991 period, the policy instrument (short term interest rates) might not have been geared to affect inflation. We would expect the results for the period during inflation targeting to be different in the sense that the central bank had the goal of keeping inflation at the target level and therefore was gearing its policy instrument towards responding to inflationary shocks. Therefore a shock to our policy instrument is expected to affect inflation in a theory consistent manner.

Similarly pre-inflation targeting, output does not respond significantly to positive interest rate shocks (see Figure 1). The response of output is not significant throughout the whole 48 months. However, the shock in interest rates reduces the monetary aggregate after about half a year until its effect fades away a few months later (see Figure 2). Theory predicts the positive interest rate shock to reduce money therefore the response of money is consistent with theory. 
The impulse response functions for the period during inflation targeting are presented in figure 4 - 6 (in appendix). We are mainly interested in Figure 6, which shows the impulse response function of prices to positive interest rate shocks. As we can see from Figure 6, a positive shock to short term interest rates still does not produce significant responses in prices. This is contrary to our expectation since we would expect a positive shock in interest rates to reduce prices. We had expected the results for the period during inflation targeting to be different since the central bank had the goal of keeping inflation at the target level and therefore was gearing its policy instrument towards responding to inflationary shocks. Therefore a shock to our policy instrument should have been effective in affecting inflation in a theory consistent manner.

On the other hand, during the inflation-targeting period the response of money and output are theory consistent. Both money and output are reduced given positive interest rate shocks. Output responds negatively from about the $6^{\text {th }}$ month up until about the $2^{\text {nd }}$ year while money responds negatively from about the $2^{\text {nd }}$ month up until the $15^{\text {th }}$ month. Both these responses are expected given a positive shock in interest rates.

From the above paragraphs it is evident that during both periods the price puzzle does not exist in Colombia. A VECM was also estimated for the whole sample period and the price puzzle is not evident in this estimation as well. The impulse response functions show that a positive shock to the interest rate was not significant in affecting prices, money and output during the whole sample period. Given that the 4-variable VECM for both periods (as well as the whole period) has not indicated the presence of the price puzzle, we do not estimate the 6-variable VAR where the food price index is included.

The VAR methodology has resulted in the price puzzle in many different countries. However, the methodology has not indicated the existence of the price puzzle in Colombia. Therefore Colombia must have some different characteristics than the countries that exhibit the price puzzle. It could be that the Central Bank of Colombia might not look at the commodity price index or other foreign variables when setting monetary policy. Therefore the information we as econometricians have might be enough to forecast future inflation and therefore we need not to include foreign variables to alleviate the price puzzle. 


\section{Conclusión}

This study has investigated the existence of the price puzzle in Colombia by using Vector Error Correction Model (VECM). We test for the price puzzle by dividing our sample into pre-1991 period (before inflation targeting started) and during inflation targeting period. We employ impulse response functions as our main tools to investigate the price puzzle.

The impulse response functions show that during both the pre-1991 and post 1991 periods, prices don't rise in response to positive shocks in short term interest rates. Therefore we conclude that Colombia does not exhibit the price puzzle. In fact, during both periods as well as the whole sample period, prices are not responsive to short-term interest rate shocks. The unresponsiveness of prices to positive interest rate shocks is not expected since we would anticipate prices to decrease due to a positive interest rate shock.

This is a first approach to the study of the price puzzle in Colombia and it is our hope to make further contributions in terms of the implications for policy making.

\section{References:}

Balke, N. S, Emery, K. M., (1994) Understanding the Price Puzzle. Economic \&amp, Financial Review. Issue $\mathrm{Q}$ (IV). pp. 15-26.

Bagliano, F. C. and. Favero, C. A. (1998). Measuring Monetary Policy with VAR Models: An Evaluation. European Economic Review, vol. 42, 1069-1112.

Bernanke, B. S., and Alan S. B. (1992), The Federal Funds Rate and the Channels of Monetary Transmission, American Economic Review. Vol. 82: 901-21.

Bernanke, B. S. and Mihov, I. (1998). Measuring Monetary Policy. Quarterly Journal of Economics, vol. 113, pp. 869-902.

Brissimis, S. N, Magginas, N. S., (2004) Forward-Looking Information in VAR Models and the Price Puzzle. Bank of Greece, Working Paper, No 10.

Christiano, J. L.,Eichenbaum, M, Evans C., (1998) Monetary policy shocks: What have we learned and to what end? NBER Working Paper no. 6400.

Eichenbaum, M. (1992). Comment on Interpreting the Macroeconomic Time Series Facts: The Effects of Monetary Policy. European Economic Review, Vol. 36. pp 1001-1011. 
Green H. W., Econometric Analysis. Prentice Hall Inc. 2000

Giordani, P. (2001) An Alternative Explanation of the Price Puzzle, Sveriges Risk Bank Working Paper Series, No. 12.

Hamilton D. J, Time Series Analysis Princeton University Press. 1994

Hanson, M. (2004). The Price Puzzle Reconsidered. Journal of Monetary Economics, forthcoming.

Jarocinski, M. (2002). VAR Puzzles in Four Big Euro-Zone Countries Under Alternative Estimation Strategies Working Paper.

Kapinos, P. (2004).Resolving the Price Puzzle: Theory and Evidence. Working Paper.

Kim, S. (2001). International transmission of U.S. monetary policy shocks: Evidence from VAR's. Journal of Monetary Economics. Vol. 48, 339-372.

Leeper, E., Sims, C. and Zha, T. 1996. "What Does Monetary Policy Do? Brooking Papers on Economic Activity.

Rudebusch, G. D., 1998. Do measures of monetary policy in a VAR make sense? International Economic Review. Vol. 39, 907-931.

Sims, C. A. (1992) Interpreting the Macroeconomic Time Series Facts, European Economic Review 36. PP. 975-1000.

Sims, C. A. (1980) Macroeconomics and Reality Econometrica. Vol. 48, pp. 1-48.

Strongin, S. (1995). The identification of monetary policy disturbances: Explaining the liquidity puzzle, Journal of Monetary Economics. Vol. 35, 463-497.

Walsh, C. E. (2000) Monetary Theory and Policy. MIT Press, Cambridge, Massachusetts. 
APPENDIX

Table 1: Unit Root Test for All the Variables

\begin{tabular}{|c|c|c|}
\hline \multirow{2}{*}{ Variable Name } & Colombia \\
\cline { 2 - 3 } & D.F. statistic & $\mathbf{5 \%}$ critical value \\
\hline $\mathrm{P}$ & -1.0434 & -2.8720 \\
\hline $\mathrm{R}$ & -2.0468 & -2.8716 \\
\hline $\mathrm{xr}$ & 1.8049 & -2.8715 \\
\hline $\mathrm{FP}$ & -2.5371 & -2.8715 \\
\hline $\mathrm{Y}$ & -0.9065 & -2.8716 \\
\hline $\mathrm{M}$ & 0.0792 & -2.8715 \\
\hline
\end{tabular}

Table 2

Unrestricted Cointegration Rank Test

\begin{tabular}{|c|c|c|c|}
\hline & Trace & 5 Percent & 1 Percent \\
\hline Eigenvalue & Statistic & Critical Value & Critical Value \\
\hline 0.168929 & 86.52131 & 47.21 & 54.46 \\
\hline 0.096285 & 34.89516 & 29.68 & 35.65 \\
\hline 0.015817 & 6.648963 & 15.41 & 20.04 \\
\hline 0.007856 & 2.200607 & 3.76 & 6.65 \\
\hline \multicolumn{4}{|l}{ Trace test indicates 2 cointegrating equation(s) at the 5\% level } \\
\hline
\end{tabular}

Table 3

Chow Breakpoint Test: 1991:01

\begin{tabular}{|l|c|c|c|}
\hline F-statistic & 7.222668 & Probability & 0.00011 \\
\hline Log likelihood ratio & 21.31538 & Probability & 0.000091 \\
\hline
\end{tabular}


Figure 1: Response of $\mathrm{Y}$ to $\mathrm{R}$ (pre-inflation targeting)

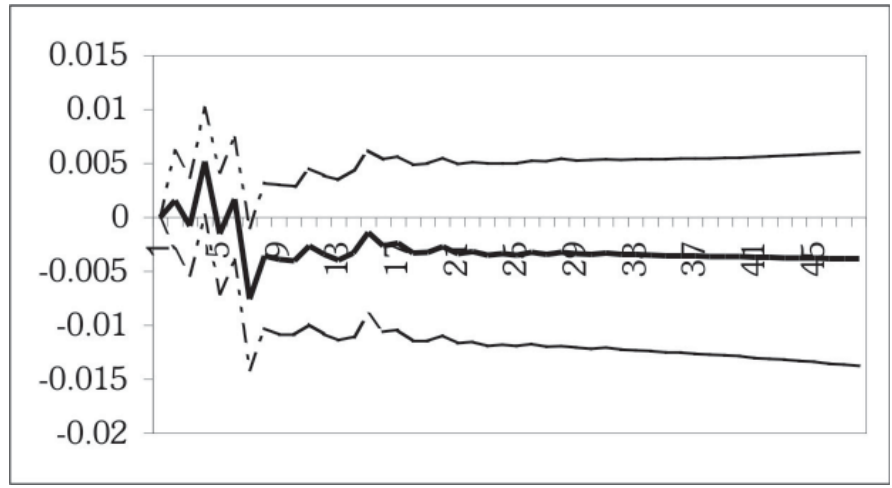

Figure 2: Response of $\mathrm{M}$ to $\mathrm{R}$ (pre-inflation targeting)

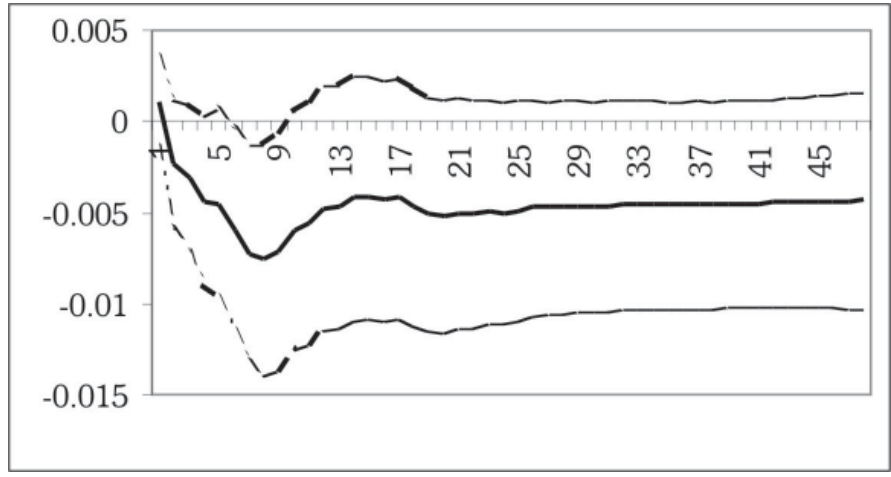

Figure 3: Response of $\mathrm{P}$ to $\mathrm{R}$ (pre-inflation targeting)

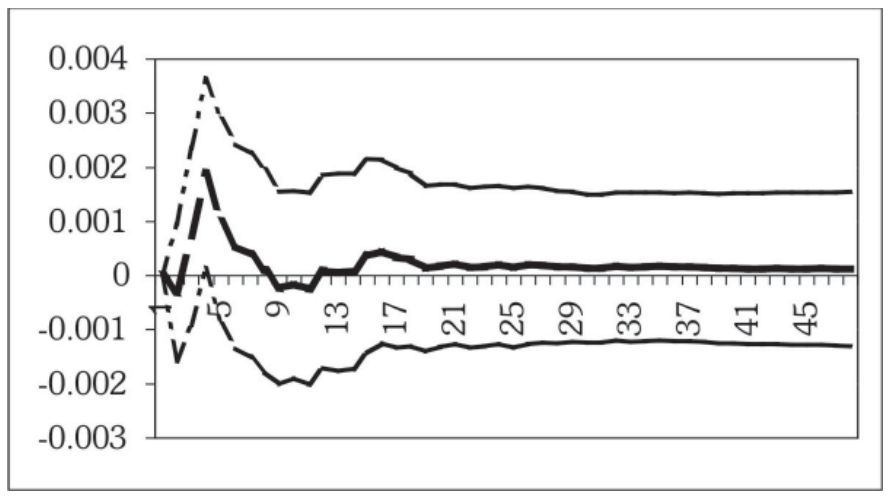


Figure 4: Response of $\mathrm{Y}$ to $\mathrm{R}$ (period during inflation targeting)

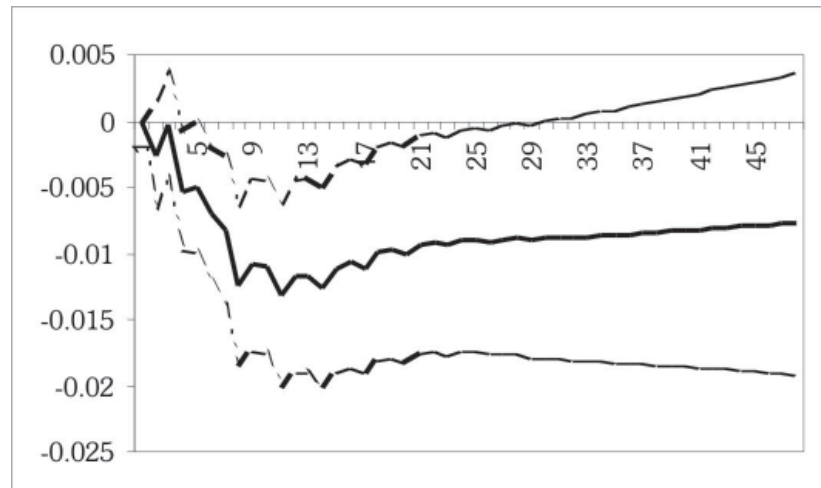

Figure 5: Response of $\mathrm{M}$ to $\mathrm{R}$ (period during inflation targeting)

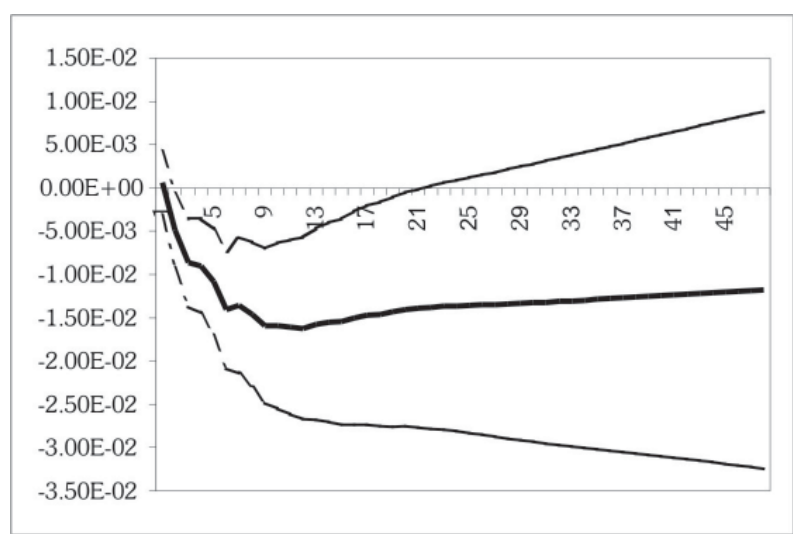

Figure 6: Response of $\mathrm{P}$ to $\mathrm{R}$ (period during inflation targeting)

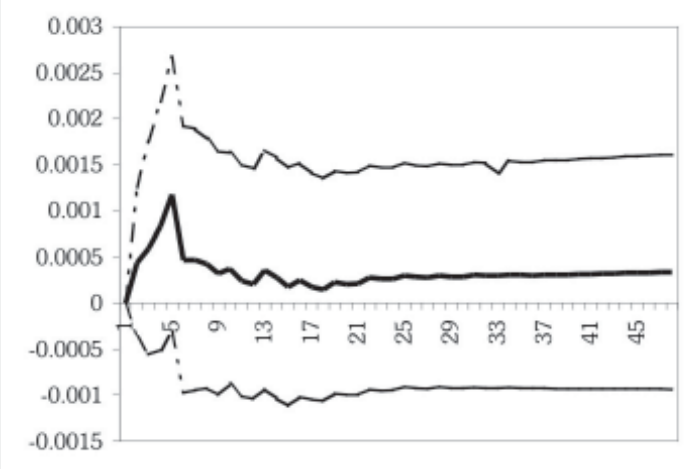




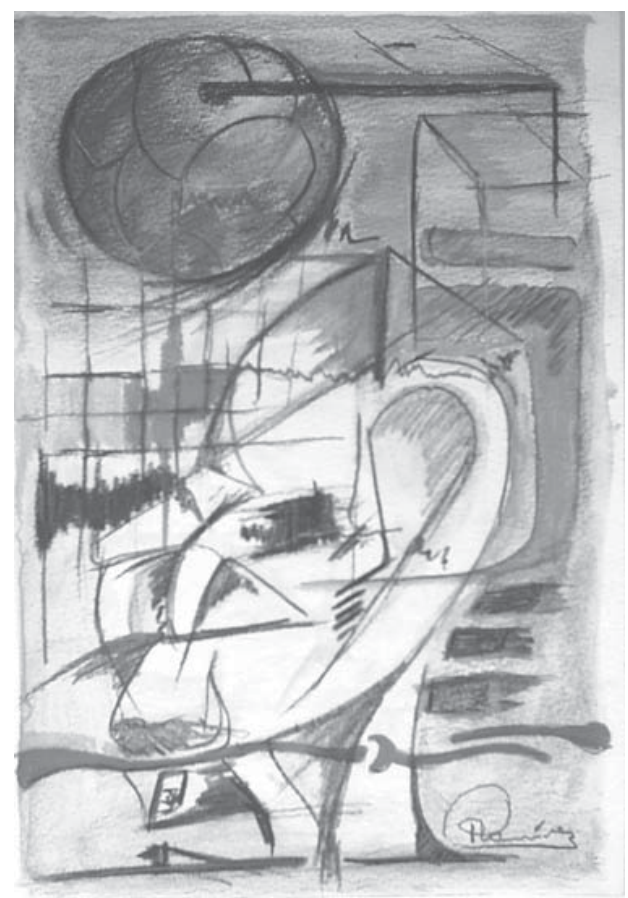

\section{Costos de transacción, un hallazgo no tan reciente. Aproximaciones a la teoría de los costos de circulación de Karl Marx}

